\title{
Strategi Konservasi Berbasis Masyarakat Pada Kompleks Situs Gua Prasejarah Bellae Kabupaten Pangkep, Provinsi Sulawesi Selatan
}

\author{
Dewi Susanti \\ Balai Pelestarian Cagar Budaya Makassar \\ Email. Dewisusantiarkeo_02@yahoo.com
}

\begin{abstract}
Abstrak : Upaya pelestarian yang selama ini dilakukan masih dominan dilakukan oleh pemerintah tanpa melibatkan masyarakat setempat. Masyarakat merupakan salah satu stakeholder yang secara tidak sadar dapat merusak serta mengubah kondisi lingkungan asli kompleks gua tersebut, karena tidak adanya ikatan dan rasa memiliki terhadap sumberdaya arkeologis di lokasi tersebut. Tujuan dari penelitian ini adalah untuk membuat strategi pencegahan kerusakan gua-gua prasejarah di Kompleks Gua Prasejarah Bellae dengan melibatkan masyarakat sebagai salah satu bagian dari stakeholder, sehingga dapat mencegah dan mengatasi kerusakan yang terjadi selama ini. Selain itu, hasil penelitian ini diharapkan dapat menciptakan kelestarian gua-gua prasejarah dan lingkungannya yang beriringan dengan perkembangan dan pertumbuhan masyarakat.

Metode yang digunakan dalam penelitian ini adalah pengumpulan data yang meliputi studi pustaka, observasi, wawancara dan Focus Group Discussion (FGD). Analisis data meliputi analisis faktor-faktor penyebab kerusakan dan kepentingan stakeholder. Tahapan terakhir adalah perumusan bentuk keterlibatan masyarakat dalam kegiatan konservasi. Berdasarkan perolehan data tentang apresiasi dan posisi, kepentingan dan keinginan masyarakat, maka dapat dirumuskan bentuk konservasi berbasis masyarakat yang mengedepankan masyarakat sebagai pemangku kepentingan.

Dari penelitian yang dilakukan, diperoleh hasil bahwa tingkat kerusakan yang terjadi pada kompleks Gua Prasejarah Belle disebabkan oleh faktor alam dan faktor manusia. Faktor manusia yang terdiri dari berbagai aktivitas yang dilakukan oleh instansi pemerintah seperti pembuatan jalan setapak dan aktivitas juru pelihara, kegiatan peneliti, aktivitas masyarakat sekitar Kompleks Gua Prasejarah Bellae yang meliputi penebangan pohon, pemanfaatan lahan dan gua, serta kebakaran lebih memiliki dampak negatif terhadap kelestarian gua-gua prasejarah di Bellae. Ancaman yang diprediksi akan terjadi yaitu penambangan gamping dan marmer. Kerusakan yang terjadi akibat aktivitas manusia ini menunjukkan belum adanya kepedulian masyarakat Bellae terhadap tinggalan arkeologis beserta lingkungannya. Selain itu, tingkat pemahaman masyarakat Bellae sangat minim, namun masyarakat Bellae memiliki keinginan untuk terlibat dalam upaya pelestarian yang dilakukan di Kompleks Gua Prasejarah Bellae.
\end{abstract}

Kata kunci: masyarakat, kerusakan, kompleks gua, lingkungan, konservasi

\begin{abstract}
So far, the conservation efforts has been predominantly carried out by the government without involving the local community. Meanwhile, society is one of the stakeholders who may cause damages and changes to the conditions of the original environment of the cave complex resulted from the absence of their bound and sense of belonging to the archaeological resources. The purpose of this study is to set up a prevention strategy for the Prehistoric Cave Complex of Bellae by involving the community as a part of the stakeholders. In addition, the results of this study are expected to create the sustainability of the prehistoric caves and the environment in association with the development and growth of the society.

The data collection methods used in this research includes literature reviews, observation, interviews and Focus Group Discussion (FGD). Data analysis includes analysis of factors that cause damage and stakeholder interests. The final stage is the formulation of the form of community involvement in conservation activities. Based on the data acquired regarding appreciation and position, interests and desires of the community, a form of community-based conservation involving the public as stakeholders can be formed.

The result shows that the damage occurs in Prehistoric Caves complex of Bellae caused by natural and human factors which consist of various activities undertaken by government agencies such as the built of pathway, activities conducted by maintainer, researchers, and communities who cut trees, the use of land and caves, and fires. Another threat is mining limestone and marble. Damage caused by human activities show the lack of awareness on archaeological site and their environment of people who live at sumounding areas of Ballae cave complex. In addition, their minimal level of understanding toward archaeological artefacts, yet they have a desire to get involved in conservation efforts undertaken in Bellae Prehistoric Caves Complex.
\end{abstract}

Keywords: society, the damage, the cave site, environment, conservation 


\section{Pendahuluan}

\section{A. Latar Belakang}

Kompleks Gua Prasejarah Bellae merupakan salah satu kawasan yang penting dalam perspektif arkeologi karena memiliki keunikan tersendiri. Di kompleks Bellae tersebut terdapat 27 situs gua prasejarah yang tersebar di sepanjang lereng dan tebing bukit. Disamping itu, terdapat pula satu situs terbuka, yaitu Pelataran Je'netaesa. Gua-gua yang terdapat di Kompleks Bellae memiliki jarak yang berdekatan, sehingga membentuk satu kawasan tersendiri. Selain itu, Kompleks Gua Prasejarah Bellae juga memiliki tinggalan arkeologis yang lengkap. Berbagai tinggalan arkeologis baik berupa artefak batu, sampah dapur, maupun lukisan dinding (rock art) masih banyak dijumpai. Temuan artefak batu seperti alat serpih dan bilah sebarannya hampir merata di semua gua yang ada di Kompleks Bellae, tetapi lancipan Maros (Maros point) hanya ditemukan di Leang Bubbuka dan Leang Kajuara, sedangkan mikrolit geometris hanya ditemukan di Leang Kajuara dan Leang Cammingkana. Lukisan dinding yang terdapat di Bellae berupa lukisan figuratif dan non-figuratif. Lukisan figuratif antara lain lukisan cap tangan yang berwarna merah dan gambar manusia yang berwarna hitam (Supriadi, 2008:5).

Hingga saat ini, nuansa masyarakat tradisional masih tergambar di dalam kawasan ini. Karakteristik masyarakat petani masih dapat dijumpai dalam kehidupan sehari-hari. Kondisi ini masih mendukung integrasi lingkungan alam kars dan kehidupan tradisional masyarakatnya. Hal tersebut dapat menjadi dukungan bagi sistem pengembangan Kawasan Cagar Budaya berwawasan pelestarian. Maka dari itu, diperlukan sebuah usaha untuk menjaga kelestariannya. Usaha yang dimaksud adalah konservasi yang berbasis masyarakat. Dalam usaha ini, masyarakat dilibatkan dan diberikan pengetahuan tentang cara mencegah dan mengatasi kerusakan lingkungan yang berakibat pada penurunan kualitas lukisan dan kerusakan lukisan sebagai akibat aktivitas manusia.

Kekayaan yang dimiliki kawasan ini perlu dijaga kelestariannya. Di sisi lain, kawasan Bellae telah ditetapkan sebagai kawasan strategis nasional dan sebagai kawasan konservasi cagar alam. Berdasarkan hasil penelitian dan beberapa upaya pelestarian yang telah dilakukan, diharapkan kawasan ini akan tetap terjaga kelestariannya.
Namun, kenyataannya sampai saat ini kondisi gua-gua prasejarah yang ada di kawasan ini terus mengalami kerusakan dan sebagian makin mengkhawatirkan. Contoh, terjadinya kerusakan pada bagian lapisan batuan dinding gua, pertumbuhan mikroorganisme pada bagian dinding gua dan lukisan dinding gua, serta terjadinya kerusakan lingkungan berupa penebangan pohon-pohon di sekitar gua, perluasan lahan pertanian, dan pemukiman akibat pertumbuhan penduduk yang semakin tinggi.

Beranjak dari kondisi tersebut maka perlu adanya upaya konservasi. Upaya konservasi yang pada umumnya dilakukan oleh pemerintah, sebaiknya beralih menjadi konservasi yang berbasis masyarakat. Dengan strategi tersebut, kondisi kerusakan yang terjadi dan faktor-faktor penyebab terjadinya kerusakan dapat diketahui dan dipahami oleh masyarakat. Hal tersebut dapat mendorong masyarakat untuk berpartisipasi menjaga kelestarian Cagar Budaya. Dalam pelaksanaannya, wawasan konservasi berbasis masyarakat perlu diperhatikan karena masyarakat merupakan subjek utama dan pengampu terdekat atau pemilik. Masyarakat sebagai pemilik Cagar Budaya perlu diberi dorongan untuk menjaga kelestarian Cagar Budaya.

Kompleks Gua Prasejarah Bellae memiliki kandungan nilai penting yang sangat tinggi, hingga menjadikan kawasan ini sebagai kebanggaan bangsa, masyarakat, serta berpotensi menjadi kebanggaan dunia (world heritage site). Pemanfaatan sumberdaya budaya yang ada pada kawasan ini dapat tetap terjaga dan terkendali sebaik-baiknya dengan pendekatan konservasi yang berbasis pada masyarakat. Pendekatan ini merupakan bentuk tanggung jawab moral masyarakat Sulawesi Selatan khususnya masyarakat Bellae, agar tetap menjaga warisan nenek moyang yang ada pada wilayah tempat tinggal mereka. Dengan demikian generasi-generasi berikutnya masih dapat menikmati kekayaan sumberdaya budaya yang ada di kawasan tersebut.

Berdasarkan hasil pemaparan di atas, muncul beberapa permasalahan yang menarik untuk dikaji yaitu.

1. Bagaimana kondisi kerusakan gua-gua prasejarah Bellae yang terjadi dari tahun ke tahun dan faktorfaktor apa saja yang menyebabkan terjadinya kerusakan tersebut?

2. Bagaimana bentuk strategi konservasi berbasis masyarakat yang dapat dilakukan terhadap Kompleks Gua Prasejarah Bellae? 


\section{B. Metode Penelitian}

Pada penelitian ini dilakukan pengumpulan data dengan sebanyak-banyaknya yang terkait dengan kegiatan-kegiatan pengelolaan yang sudah dilakukan, jenis kerusakan lukisan dan peran stakeholder. Stakeholder yang dimaksud dalam penelitian ini adalah individu/ perorangan atau kelompok yang berkepentingan dengan pengelolaan dan pelestarian Kompleks Gua Prasejarah Bellae, baik yang terkait secara langsung maupun yang tidak langsung.

\section{Pengumpulan Data}

Pengumpulan data penelitian dilakukan melalui empat cara yaitu studi pustaka, observasi, wawancara dan Focus Group Discussion (FGD). Studi pustaka yang dimaksudkan adalah penelusuran dan mendapatkan data serta informasi dari berbagai sumber baik berupa laporan, buku, makalah, tesis, skripsi, dan artikel-artikel baik dari sumber internet maupun sumber lainnya ada kaitannya dengan penelitian yang dilakukan.

Observasi atau pengamatan dilakukan dengan melakukan pengamatan pada Kawasan Gua-Gua Prasejarah Bellae, dan mengumpulkan semua data yang berkaitan dengan keterancaman Kawasan dan Guaguanya. Pengamatan baik berupa aktivitas penduduk, pengujung, kondisi gua, dan lingkungannya. Obeservasi ini dilakukan dengan membuat catatan, memotret dan menentukan waktu serta tempat untuk pelaksanaan Focus Group Discussion (FGD).

Wawancara dilaksanakan untuk mendapatkan data yang belum terhimpun dalam pengamatan. Wawancara yang dilakukan dalam penelitian ini, cenderung tidak formal namun bersifat mendalam dan dapat dikembangkan oleh peneliti sendiri. Wawancara ini dilakukan terhadap masyarakat yang bermukim disekitar kawasan Bellae, pengunjung, dan instansi yang memiliki keterkaitan dan hubungan dengan lokasi dan masalah penelitian. Instansi yang dimaksud yaitu terdiri dari Balai Pelestarian Cagar Budaya Makassar, Balai Arkeologi Makassar, Akademisi (arkeologi Universitas Hasanuddin), Taman Nasional Bantimurung Bulusaraung, Dinas Kebudayaan dan Pariwsata Kabupaten Pangkep, Dinas Kehutanan Kabupaten Pangkep, kelompok pecinta alam (Edelweis), dan perangkat desa.

Focus Group Discussion (FGD). FGD pada dasarnya merupakan satu alternatif yang penting dalam sebuah kajian yang bersifat kualitatif. Ada beberapa tujuan penting FGD yaitu (1) menyerap beberapa informasi (pengetahuan, pandangan, dan sikap/respon) dari sejumlah orang (yang menjadi partisipan) di suatu tempat, dalam suatu waktu, dan untuk suatu acara yang telah dirancang; (2) informasi itu diharapkan sangat bervariasi sehingga menjadi pengkayaan bagi para pengkaji, dan (3) di antara partisipan bukan saja bisa menyampaikan tetapi juga bisa mengkritisi pandangan, sikap, dan pengetahuan partisipan lain secara argumentatif. Data yang diperoleh dari hasil studi pustaka, observasi lapangan, wawancara dan FGD akan diolah dalam bentuk narasi dan tabel.

\section{Analisis Data}

Analisis data meliputi analisis faktor-faktor penyebab kerusakan dan kepentingan stakeholder. Pada analisis dilakukan identifikasi faktor-faktor yang menyebabkan terjadinya kerusakan di Kompleks Gua Prasejarah Bellae, baik faktor alam maupun faktor manusia. Faktor alam mengacu pada hasil analisis klimatologi yang telah dilakukan, dan faktor manusia meliputi aktivitas para stakeholder.

Stakeholder yang dimaksud dalam penelitian ini adalah individu/ perorangan atau kelompok yang berkepentingan dengan pelestarian Kompleks Gua Prasejarah Bellae, yang terkait secara langsung maupun tidak langsung. Dalam analisis stakeholder hal utama yang dilakukan adalah melakukan identifikasi beragam individu/ perorangan, kelompok, dan institusi yang terkait dengan kelestarian dan pemanfaatan Kompleks Gua Prasejarah Bellae. Stakeholder yang telah diindentifikasi kemudian diklasifikasi berdasarkan posisi, kepentingan, dan kebutuhannya. Stakeholder yang memiliki posisi, kepentingan, dan kebutuhan yang sama sebagai instansi yang memiliki wewenang terhadap pelestarian Kompleks Bellae yaitu Balai Pelestarian Cagar Budaya Makassar, Taman Nasional Bantimurung Bulusaraung (TN. BABUL), Dinas Kehutanan Kabupaten Panngkep, dan Pemerintah Setempat (Kelurahan). Stakeholder yang memiliki posisi, kepentingan, dan kebutuhan untuk pemanfaatan yaitu lembaga peneliti seperti Balai Arkeologi Makassar (BALAR) dan akademisi (Arkeologi UNHAS), Dinas Kebudayaan dan Pariwisata Kabupaten Pangkep, Dinas Pertambangan Kabupaten Pangkep, Pecinta alam 
(Edelweis), masyarakat lokal, dan pengunjung.

\section{Perumusan Bentuk konservasi yang Berbasis Masyarakat}

Tahapan terakhir adalah perumusan bentuk keterlibatan masyarakat dalam kegiatan konservasi. Berdasarkan perolehan data tentang apresiasi dan posisi, kepentingan dan keinginan masyarakat, maka dapat dirumuskan bentuk konservasi berbasis masyarakat yang mengedepankan masyarakat sebagai pemangku kepentingan.

\section{Pembahasan}

\section{A. Kondisi Kerusakan}

\section{Faktor Alam}

Berdasarkan hasil penelitian yang dilakukan oleh peneliti, baik melalui pengamatan langsung maupun studi pustaka diketahui bahwa kerusakan yang terjadi pada gua-gua prasejarah di Kompleks Bellae dari waktu ke waktu semakin parah. Berdasarkan data mengenai iklim makro yang terjadi di Kompleks Gua Prasejarah Bellae, diketahui bahwa lama penyinaran matahari pada bulan Januari hingga bulan September mengalami peningkatan, sedangkan pada bulan Oktober sampai Desember mengalami penurunan. Diketahui bahwa lama penyinaran matahari di lingkungan Situs Minasatene terendah terjadi pada bulan Desember dan Januari. Temperatur udara juga mengalami peningkatan pada siang hari dan turun secara drastis pada malam hari. Fluktuasi suhu tersebut mengakibatkan tingkat kelembaban yang terjadi di Kompleks Gua Prasejarah Bellae semakin tinggi yaitu rata-rata berkisar antara 35- $50 \%$. Tingkat kelembaban tersebut dengan mudah memicu pertumbuhan mikroorganisme yang terjadi dalam gua-gua prasejarah. Air yang terdapat di dalam dan di sekitar lingkungan gua merupakan salah satu penyebab terjadinya kelembaban dalam gua, sehingga dengan mudah dapat memicu pertumbuhan mikroorganisme seperti algae dan moss. Pertumbuhan mikroorganisme ini akan mempercepat terjadinya pelapukan pada bagian lapisan batuan dan lukisan. Pada musim kemarau algae dan moss akan kering, hal ini dikhawatirkan akan menyebabkan pengelupasan.

Contoh kasus kerusakan yang terjadi pada guagua prasejarah yaitu dapat kita temukan pada Leang Lompoa. Pada tahun 2007 lukisan cap tangan masih nampak jelas dan masih teridentifikasi, namun bagian lapisan batuan sudah mengalami pengelupasan dan penggaraman. Pengelupasan lapisan batuan nampak pada bagian atas lukisan cap tangan dan di sekitar lukisan tersebut terdapat juga aliran air yang memicu terjadinya pengelupasan dan penggaraman permukaan lapisan batuan. Namun demikian kerusakan lukisan tersebut dibiarkan tanpa ada upaya apapun. Pada tahun 2015 tampak bahwa lukisan tersebut hampir semuanya tertutup algae. Permasalahan tersebut apabila dibiarkan tanpa ada upaya apapun dapat menyebabkan hilangnya lukisan cap tangan, karena lama kelamaan akan terjadi pengelupasan akibat mengeringnya algae yang menutupi lukisan tersebut. Kondisi lukisan manusia di Leang Lompoa juga sangat parah. Di tahun 2007 kondisi tiga lukisan manusia yang ada di gua tersebut masih nampak jelas demikian pula lapisan dinding gua yang memiliki lukisan belum mengalami pengelupasan yang parah. Pada tahun 2015 lukisan tersebut hanya tersisa satu dan sudah tidak utuh, sedangkan dua lukisan lainnya sudah terkelupas dan hilang. Batuan dinding juga nampak parah karena hampir semua batuan dinding mengalami pengelupasan.

\section{Faktor Manusia}

Hasil pengamatan menunjukkan bahwa kerusakan gua dan lingkungan di Kompleks Gua-Gua Prasejarah Bellae, tidak hanya terjadi akibat kondisi alam tetapi juga disebabkan oleh faktor manusia. Berdasarkan pengamatan yang dilakukan, diketahui bahwa ada beberapa pihak (stakeholder) yang memiliki kepentingan terhadap Kompleks Gua Prasejarah Bellae. Aktivitas stakeholder pada Kompleks Gua Prasejarah Bellae secara tidak sadar banyak memberikan dampak yang negatif terhadap tinggalan sumberdaya arkeologi dan lingkungannya. Untuk memperjelas mengenai kepentingan dan dampak yang ditimbulkan oleh stakeholder, maka akan diuraikan sebagai berikut.

\section{Instansi Pemerintah (Balai Pelestarian Cagar Budaya Makassar) \\ Pembuatan Jalan Setapak}

Tujuan BPCB Makassar dalam membuat fasilitas seperti jalan setapak di sekitar gua-gua adalah agar dapat memudahkan akses menuju gua tersebut. Pembuatan pagar dimaksudkan agar dapat mencegah terjadinya perusakan terhadap tinggalan-tinggalan 
yang ada di dalam gua. Namun demikian secara tidak sadar dengan pembuatan fasilitas jalan setapak tersebut, pihak BPCB Makassar telah melakukan perusakan baik terhadap temuan permukaan situs maupun terhadap lingkungan situs itu sendiri.

\section{Aktivitas Juru Pelihara}

Kontribusi yang diberikan oleh juru pelihara situs dalam penurunan kualitas tinggalan arkeologi yang ada di Kompleks Gua Prasejarah Bellae adalah dari cara-cara mereka membersihkan lingkungan. Pada umumnya cara yang dilakukan oleh juru pelihara dalam menjaga kebersihan lingkungan situs dan lantai gua yaitu dengan cara menyapu menggunakan sapu lidi. Tanpa disadari bahwa cara yang dilakukan oleh juru pelihara tersebut justru mengakibatkan terjadinya pergeseran temuan permukaan dan bahkan kadang ada yang hilang.

\section{Kegiatan Peneliti}

Komunitas peneliti juga tidak sedikit kontribusinya dalam menurunkan kualitas tinggalan arkeologi yang terakumulasi di dalam situs. Peneliti biasanya melakukan ekskavasi pada lantai gua dan halaman gua serta seringkali juga mengambil sampel temuan untuk kepentingan analisis dan untuk kepentingan lainnya. Aktivitas peneliti ini tanpa disadari telah mengakibatkan terjadinya penyusutan pada lantai, halaman gua dan temuan. Catatan mengenai temuan yang diambil sebagai sampel analisis laboratorium masih kurang, tidak menginformasikan dan mempublikasikan hasil-hasil penelitian yang telah dilakukan pada kompleks gua tersebut.

\section{Masyarakat Sekitar Kompleks Gua Prasejarah Bellae}

Berdasarkan data yang diperoleh dari Badan Pusat Statistik (BPS) Kabupaten Pangkep dan data dari Kelurahan, diketahui bahwa tingkat pendidikan masyarakat yang bermukim di sekitar Kompleks Gua Prasejarah Bellae sebagian besar hanya tamat sekolah dasar (SD). Adapun mata pencahariannya pada umumnya adalah petani. Masyarakat Bellae yang memiliki pendidikan SMP dan SMU hanya sedikit sedangkan masyarakat yang memiliki pendidikan tinggi dapat dihitung jari atau tergolong sangat sedikit. Tingkat pendidikan masyarakat ini sangat berdampak pada keberadaan sumberdaya arkeologi yang ada di kompleks gua tersebut. Pengetahuan masyarakat terhadap sumberdaya arkeologi hanya pada keberadaan gua dan lukisan yang ada dalam gua, sehingga beberapa aktivitas yang dilakukan oleh masyarakat tanpa disadari dapat menyebabkan terjadinya kerusakan baik pada gua maupun lingkungan sekitar gua itu sendiri. Aktivitas yang dilakukan masyarakat di sekitar Kompleks Gua Prasejarah Bellae adalah penebangan pohon, pemanfaatan lahan dan gua, dan pembakaran lahan.

\section{Pengunjung}

Selama ini Kompleks Gua Prasejarah Bellae telah menjadi salah satu tujuan wisata di Sulawesi Selatan. Tujuan pengunjung yang datang pada kompleks ini ada dua hal, yaitu melakukan wisata budaya, dan wisata terapi ikan. Meningkatnya jumlah pengunjung yang datang pada kompleks ini selain memberikan dampak positif, juga memberikan dampak negatif terhadap lingkungan dan sumberdaya arkeologis yang ada di kawasan Bellae. Dampak negatif dari aktivitas pengunjung antara lain berupa vandalisme yaitu adanya coretan dan tulisan pada bagian dinding gua bahkan seringkali dilakukan pada lukisan dinding gua. Salah satu akibat aktivitas pengunjung dapat kita lihat di Leang Kassi. Leang Kassi ini dipilih karena dianggap mewakili lokasi gua sangat dekat dari jalan raya (akses jalan menuju Bellae). Selain itu, gua ini juga sering sekali dijadikan objek wisata dan tingkat kunjungan sangat tinggi terutama pada hari-hari libur atau pada saat sore hari. Tingkat keramaian pengunjung pada leang ini disebabkan karena di lingkungan Leang Kassi terdapat kolam penampungan air PDAM. Kolam ini dimanfaatkan oleh pengunjung dan masyarakat sebagai kolam renang. Di sisi lain, juga diketahui bahwa area di sekitar Leang Kassi ini dimanfaatkan sebagai lahan peternakan bebek. Padatnya tingkat kunjungan pada leang ini dan semakin banyaknya pemanfaatan yang dilakukan di sekitarnya dapat menyebabkan kerusakan lingkungan dan menimbulkan dampak 
pada Leang Kassi. Tingkat kerusakan yang terjadi pada leang ini dari tahun ke tahun semakin parah dan mengkhawatirkan. Pada tahun 2014 lukisan dinding gua di Leang Kassi, belum mengalami kerusakan berupa coretan yang dilakukan oleh pengunjung. Pada tahun 2015 lukisan tersebut telah mengalami kerusakan akibat ulah pengunjung.

\section{Penambangan Gamping dan Marmer}

Penambangan gamping dan marmer ini diprediksi kedepannya akan menjadi penyebab terjadinya kerusakan di sekitar Kompleks Gua Prasejarah Bellae. Hal ini mengingat bahwa di sekitar kawasan cagar budaya Maros-Pangkep terdapat aktivitas penambangan baik yang bersifat perorangan maupun perusahaan. Penambangan perorangan terutama dilakukan masyarakat setempat untuk mencari kotoran kelelawar dan burung di gua-gua untuk dijadikan pupuk. Namun, penambangan ini sudah jarang dilakukan lagi. Penambangan oleh perusahaan besar, terutama untuk mendapatkan batu marmer atau bahan pembuatan semen, intensitasnya cukup besar, sehingga kerusakan yang ditimbulkan terhadap lingkungan juga besar. Selain kehilangan bukit-bukit gamping, proses penambangan dengan ledakan juga berpotensi merusak gua-gua dalam radius sekitar $300 \mathrm{~m}$, karena getarannya. Dampak lain dari aktivitas ini adalah debu yang dapat tersebar luas di lingkungan tempat penambangan termasuk di situs-situs gua. Polusi debu berpotensi memberikan dampak negatif secara langsung dan tidak langsung terhadap sumberdaya arkeologi dan lingkungan sekitar di Kompleks Gua Prasejarah Bellae.

Untuk tetap menjaga kelestarian Kompleks Gua Prasejarah Bellae, perlu adanya kebijakan dan pelestarian sumberdaya arkeologi. Kebijakan dan pelestarian tidak lagi harus dilihat dari perspektif arkeologi semata, tetapi dari berbagai perspektif pihak-pihak yang berkepentingan yang meliputi masyarakat Bellae, BPCB Makassar, Lembaga peneliti (BALAR Makassar dan akademisi), TN. Babul, Dinas Kehutanan Kab. Pangkep, Dinas Kebudayaan dan Pariwisata Kab. Pangkep, Dinas Pertambangan Kab. Pangkep, pemerintah setempat, pecinta alam dan pengunjung. Hal ini, dilakukan untuk mengetahui keinginan dari berbagai pihak (stakeholder) terhadap sumberdaya arkeologi, serta untuk mengurangi potensi munculnya konflik kepentingan. Di sisi lain, hal ini dilakukan untuk mewujudkan pelestarian sumberdaya arkeologi yang dilakukan secara bersama oleh pihak-pihak terkait dan paling utama adalah melibatkan masyarakat setempat. Sejalan dengan perkembangan ilmu pengetahuan dalam bidang arkeologi, diketahui bahwa untuk menjaga kelestarian sumberdaya arkeologi masyarakat setempat harus dilibatkan. Tujuan pelibatan masyarakat tersebut yaitu agar masyarakat dapat memahami dan terlibat secara langsung dalam upaya menjaga kelestarian Kompleks Gua Prasejarah Bellae.

Berdasarkan pemaparan yang telah diuraikan di atas, tentang banyaknya stakeholder yang memiliki kepentingan dan kebutuhan terhadap Kompleks Gua Prasejarah Bellae, maka perlu dilakukan analisis untuk menentukan posisi, kepentingan serta kebutuhan setiap stakeholder terhadap Kompleks Gua Prasejarah Bellae. Untuk memudahkan dalam melakukan analisis ini, maka salah satu alat bantu yang digunakan adalah analisis bawang bombay. Analisis ini merupakan sebuah cara untuk menganalisis perbedaan kepentingan dan kebutuhan dari pihakpihak stakeholder. Dalam permasalahan yang terjadi di Kompleks Gua Prasejarah Bellae diketahui bahwa ada beberapa kelompok stakeholder yang terdiri dari pelestari, peneliti, dan pihak pemanfaat. Stakeholder yang terdiri dari pihak pelestari memiliki kepentingan untuk menjaga kelestarian Kompleks Gua Prasejarah Bellae. Pihak peneliti memiliki kepentingan untuk tetap melakukan penelitian pada Kompleks Gua Prasejarah Bellae untuk memajukan ilmu pengetahuan dan pengembangan ilmu pengetahuan. Pihak pemanfaat memiliki kepentingan untuk pemanfaatan lahan-lahan di sekitar Kompeks Gua Prasejarah Bellae yang dapat meningkatkan PAD. Berikut adalah hasil analisis bawang bombay dalam bentuk matriks

Berdasarkan pada analisis stakeholder, maka perlu disusun sebuah konsep yang dapat mencakup semua kepentingan. Hal ini dilakukan untuk mengurangi potensi konflik yang mungkin terjadi di Kompleks Gua Prasejarah Bellae. Oleh karena itu, pihak pemerintah 


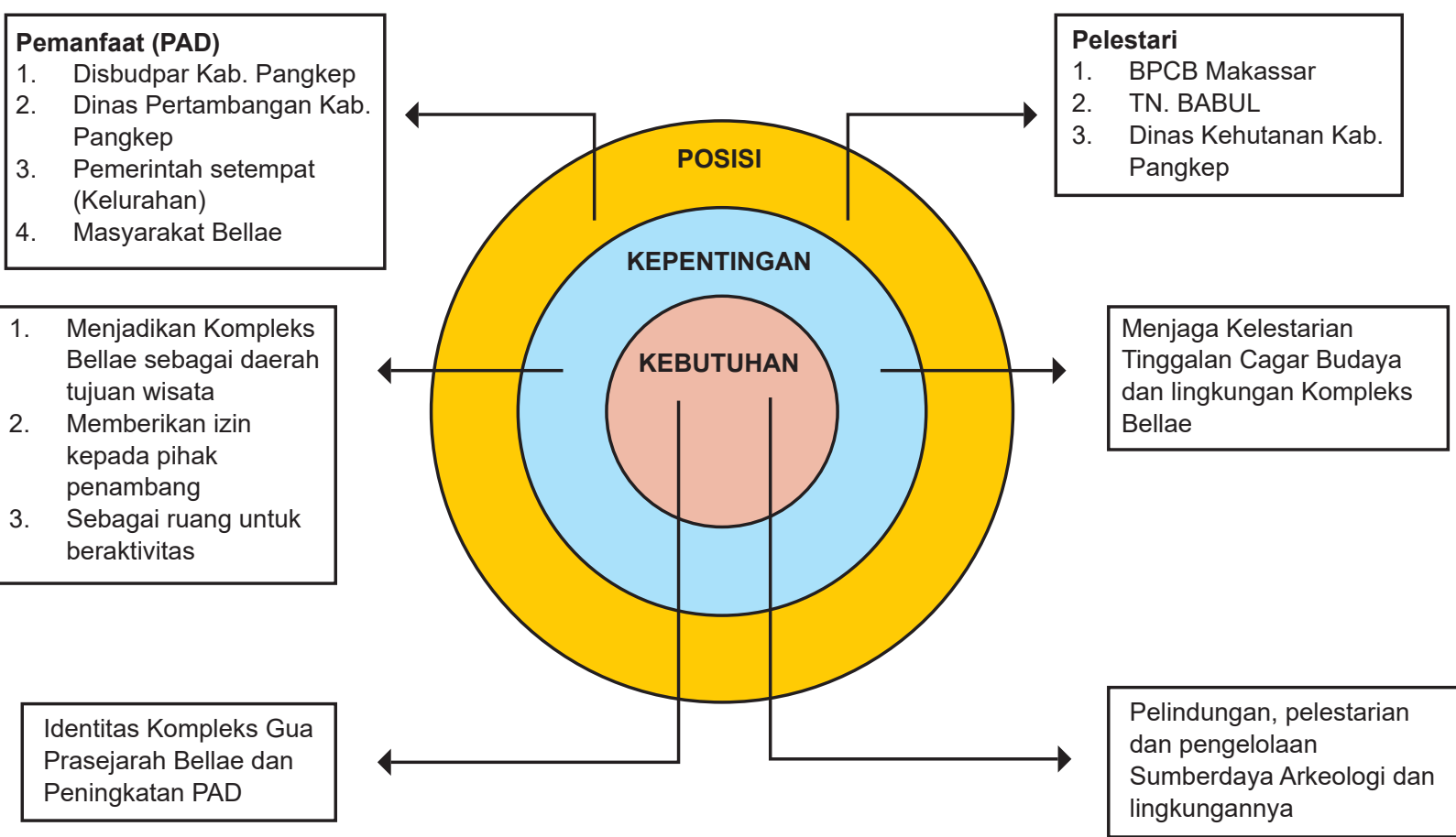

Gambar. Alat Bantu Analisis Bawang Bombay Antara Pihak Pelestari dengan Pemanfaat (PAD)

Tersedianya ruang untuk kegiatan kepencinta alaman, memanfaatkan ruang dan untuk tempat menikmati keindahan alam dan budaya
Lahan melakukan aktivitas untuk peningkatan ekonomi dan kepuasan batin
Peneliti

1. Balai Arkeologi Makassar (BALAR)

2. Akademisi (Arkeologi UNHAS)

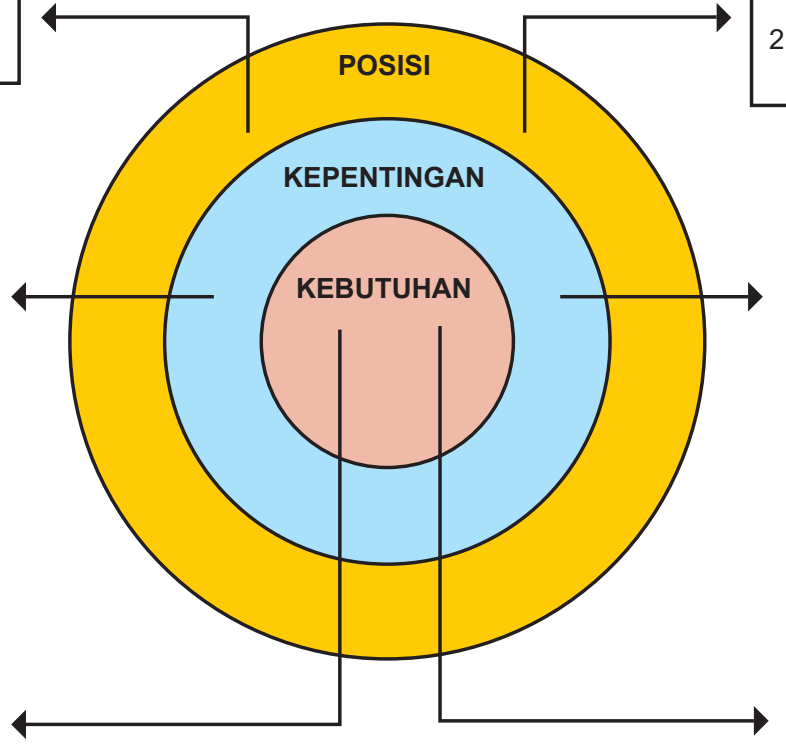

Melakukan penelitian

Pengembangan IImu Pengetahuan dan kepuasan intelektual

Gambar. Alat Bantu Analisis Bawang Bombay 
yang memiliki wewenang tertinggi, dalam hal ini pihak pengelola BPCB Makassar dan pihak TN. BABUL perlu melalukan sosialisasi dan koordinasi kepada masyarakat. Koordinasi tersebut menyangkut pentingnya menjaga kelestarian tinggalan gua-gua prasejarah dan lingkungannya serta membuat solusi untuk mengalihkan aktivitas masyarakat dari memanfaatkan gua dan memanfaatkan lingkunganya ke kegiatan yang dapat mendukung peruntukan pelestarian tinggalan arekologis beserta lingkungannya.

Kompleks Gua Prasejarah Bellae merupakan daerah yang rawan kerusakan. Kerusakan dapat terjadi akibat perubahan alamiah atau disebabkan oleh ulah manusia baik disadari maupun tidak. Kerusakan kawasan dalam skala besar dapat menyebabkan degradasi lingkungan yang akan merugikan masyarakat dalam jangka panjang. Kompleks Gua Prasejarah Bellae merupakan kawasan yang memiliki cukup banyak kekayaan baik berupa kekayaan budaya maupun kekayaan alam. Kompleks Gua Prasejarah Bellae saat ini, mengalami ancaman kerusakan sehingga perlu dikonservasi secara terukur dan terpadu. Keterpaduan upaya konservasi ini perlu melibatkan peran serta masyarakat di sekitar kompleks Bellae karena merekalah pemangku utama dari kelestarian sumberdaya arkeologi dan sumber daya alam. Selain itu, upaya yang akan dilakukan ini juga akan memberikan manfaat baik secara sosial maupun ekonomi. Melalui tulisan ini, maka akan dicoba membuat sebuah upaya konservasi dalam penanganan kerusakan yang terjadi selama ini di Kompleks Gua Prasejarah Bellae dan strategi pelibatan masyarakat dalam menjaga kelestariannya

\section{B. Strategi Konservasi Kompleks Gua Prasejarah Bellae}

Strategi konservasi yang akan dilakukan di Kompleks Gua Prasejarah Bellae adalah konservasi yang berbasis masyarakat. Menurut Tanudirjo (2005) masyarakat adalah elemen utama yang berperan dalam upaya pelaksanaan konservasi, karena masyarakat itu sendiri yang dapat memberikan arti dan nilai terhadap sumberdaya arkeologi yang ada di Kompleks Gua Prasejarah Bellae. Pandangan masyarakat terhadap sumberdaya arkeologi bervariasi, ada yang beranggapan sebagai sarana hiburan dan rekreasi, pelampiasan hobby, atau ada juga yang beranggapan sebagai bagian dari industri pariwisata yang dapat menghasilkan uang dan memberikan manfaat secara ekonomi pada masyarakat setempat (Tanudirdjo, 2005: 1).

Hasil wawancara dan FGD (Focus GroupDiscussion) yang telah dilakukan kepada masyarakat setempat diperoleh informasi bahwa selama ini Kompleks Gua Prasejarah Bellae hanya dijadikan sebagai tempat untuk rekreasi dan pelampiasan hobby, bukan sebagai kawasan wisata yang dapat menjadi sumber pendapatan dan menyejahterakan masyarakat Bellae. Melalui penelitian ini mencoba membuat strategi konservasi Kompleks Gua Prasejarah Bellae yang berbasis masyarakat. Diharapkan melalui penelitian ini dapat memberikan manfaat bagi semua kelompok stakeholder yang memiliki kepentingan pada Kompleks Gua Prasejarah Bellae dan yang utama adalah melibatkan masyarakat Bellae dalam menjaga kelestarian sumberdaya arkeologi dan lingkungannya. Dengan pelibatan masyarakat diharapkan dapat memberikan manfaat dan secara tidak langsung masyarakat akan memiliki ikatan emosional dengan tinggalan sumberdaya arkeologi tersebut.

Hal utama yang harus dilakukan sebelum perumusan strategi konservasi berbasis masyarakat adalah penanganan konflik yang selama ini terjadi pada Kompleks Gua Prasejarah Bellae. Konflik yang terjadi pada kompleks gua tersebut menimbulkan dampak yang negatif terhadap tinggalan sumberdaya arkeologi yang ada di Kompleks Gua Prasejarah Bellae. Berikut akan diuraikan mengenai penangan konflik, antisipasi faktor penyebab kerusakan dan pelibatan masyarakat dalam menjaga kelestarian Kompleks Gua Prasejarah Bellae serta bagaimana cara agar dapat menyejahterakan kehidupan masyarakat Bellae.

\section{Mengatasi Konflik}

Berdasarkan hasil analisis konflik, diketahui bahwa konservasi Kompleks Gua Prasejarah Bellae dapat memberikan manfaat jika sistem penanganan kerusakan sumberdaya arkeologi dan lingkungannya dapat dilaksanakan secara kolaboratif. Dalam konteks cagar budaya, pelestarian dimaknai sebagai upaya pengelolaan sumber daya budaya yang menjamin pemanfaatannya secara bijaksana serta menjamin 
kesinambungan persediaannya dengan tetap memelihara dan meningkatkan kualitas nilai dan keanekaragamannya. Pada hakikatnya pelestarian cagar budaya merupakan kegiatan berkesinambungan (sustainable activity) yang dilakukan secara terus menerus dengan perencanaan yang matang dan sistematis, sehingga pemanfaatannya dapat dirasakan oleh seluruh lapisan masyarakat yang merupakan pemilik syah cagar budaya.

Pelestarian cagar budaya tidak hanya terkait dengan objek cagar budayanya saja, tetapi juga meliputi aspek-aspek lain baik yang terkait langsung maupun tidak langsung. Berdasarkan kenyataan bahwa cagar budaya tidaklah berdiri sendiri. Dalam kajian arkeologis, jelas terlihat bahwa setiap cagar budaya terikat dengan konteksnya baik, lingkungan maupun budaya secara umum. Oleh karena itu, pelestarian cagar budaya harus mencakup pelestarian konteks cagar budaya itu sendiri termasuk lingkungan. Secara global, gagasan ini pun telah diterapkan oleh sebagian besar negara, bahkan UNESCO dalam hal ini merumuskannya dalam konsep Natural Heritage Landscape, dimana cagar budaya merupakan satu kesatuan dengan bentang alam dan bentang budaya. Hal ini berarti, pelestarian cagar budaya tidak dapat lagi dilepaskan dari pelestarian lingkungan atau alam.

Upaya pelestarian dapat dilaksanakan dalam tiga kegiatan utama yaitu perlindungan, pemanfaatan, dan pengembangan. Perlindungan dimaksudkan untuk mencegah agar cagar budaya tidak mengalami kerusakan dan kehancuran. Pengembangan dapat diartikan sebagai upaya untuk menjaga kualitas penampilan cagar budaya agar dapat difungsikan terus seperti fungsi semula atau untuk fungsi lain yang sesuai dengan ketentuan undang-undang. Pemanfaatan, memberikan kegunaan bagi peningkatan kesejahteraan masyarakat, baik untuk pendidikan dan pengembangan ilmu pengetahuan, ekonomi, maupun kebudayaan di masa kini dan mendatang.

Dalam konteks penanganan kerusakan di Kompleks Gua Prasejarah Bellae, peran serta masyarakat harus diakomodasikan dalam setiap proses pengambilan keputusan. Pada tahap awal proses observasi, perencanaan yang meliputi persiapan, perumusan konsep dan sampai pada rekomendasi sebaiknya secara intens melibatkan masyarakat.

\section{Upaya Penangan Kerusakan}

\section{Penanganan Lingkungan}

Dalam rangkan melakuka penanganan iklim makro, usaha yang dapat dilakukan adalah pihak BPCB Makassar dan TN. BABUL selaku instansi pemerintah adalah melakukan kerjasama dengan pihak BMKG setempat agar dapat didukung dengan peralatan untuk pembuatan stasiun klimatologi mini. Sehingga selanjutnya pihak pengelola dapat melakukan sosialisasi mengenai stasiun klimatologi yang dibuat pada kompleks gua tersebut. Untuk mencegah terjadinya kapilarisasi dan mengurangi tingkat penyinaran matahari pada dinding gua maka perlu dilakukan penanganan lingkungan. Hal pertama yang harus dilakukan adalah pengalihan aliran air. Sehingga air yang mengalir kearah lukisan dapat dialihkan kearah lain yang tidak memiliki lukisan, mengingat aliran air akan mempercepat terjadinya pengelupasan dinding gua dan pertumbuhan mikroorganisme. Untuk mencegah terjadinya pelapukan yang terus menerus terjadi pada bagian mulut gua yang cenderung terbuka akibat penyinaran matahari, maka perlu dilakukan upaya penanaman pohon di sekitar gua-gua. Jenis pohon yang akan ditanam harus jenis tanaman endemik dan sesuai dengan kondisi lingkungan serta sesuai dengan prinsip konservasi lingkungan. Untuk mewujudkan upaya tersebut maka pihak BPCB Makassar dan TN. BABUL melakukan koordinasi dengan stakeholder lain seperti Dinas Kebudayaan dan Pariwisata kab. Pangkep, Dinas Kehutanan kab. Pangkep, Pencinta Alam, Akademis, Juru Pelihara dan Masyarakat setempat dengan tujuan agar pada saat pelaksanaan konservasi lingkungan ini semua stakeholder dapat terlibat dan melaksanakan secara bersama-sama.

\section{Masyarakat Di Sekitar Kompleks Bellae}

Pemanfaatan oleh masyarakat yang dimaksud dalam tulisan ini adalah pemanfaatan lahan dan gua. Pemanfaatan yang dilakukan masyarakat Bellae hingga saat ini masih dapat kita temukan, hal tersebut diakibatkan karena kurangnya pemahaman dan pengetahuan mereka tentang pelestarian gua-gua prasejarah dan lingkungannya. Selain itu, karena kurangnya sosialisasi yang dilakukan pemerintah terhadap masyarakat dan tidak adanya upaya pelibatan masyarakat dalam setiap kegiatan yang dilakukan baik oleh pemerintah maupun oleh pihak akademisi. 
Mengingat bahwa akar permasalahan dari kerusakan gua-gua di kompleks Bellae karena kurangnya pengetahuan masyarakat tentang pentingnya menjaga dan melestarikan gua-gua prasejarah dan lingkungannya. Berdasarkan dari hasil pengamatan di lapangan maka ada beberapa hal yang perlu dilakukan untuk meningkatkan pengetahuan/pemahaman masyarakat yaitu pendidikan lingkungan, penanaman etika lingkungan, dan pembiasaan perilaku yang ramah lingkungan.

\section{Pelibatan masyarakat}

Penanganan faktor penyebab terjadinya kerusakan tidak akan mencapai hasil yang maksimal, apabila tidak melibatkan masyarakat setempat. Pelibatan masyarakat dalam bentuk upaya konservasi akan membuat masyarakat menjadi lebih berdaya, baik secara politik maupun ekonomi. Masyarakat Bellae menjadi lebih berdaya, sehingga memiliki kekuatan dan kekuasaan untuk melestarikan gua-gua prasejarah beserta lingkungannya, memiliki wewenang untuk mengambil keputusan, serta dapat memberikan akses kepada masyarakat untuk mencari nafkah. Untuk mendukung keberhasilan konservasi yang berbasis masyarakat dalam usaha penanganan kerusakan gua-gua prasejarah dan lingkungannya, diperlukan sumberdaya manusia yang memiliki kemampuan dan keahlian. Maka dari itu, masyarakat diberikan berbagai pelatihan untuk meningkatkan pengetahuan dan keberdayaan masyarakat. Contoh pelatihan yang dilakukan adalah manajemen organisasi, pembuatan souvenir, pengolahan makanan tradisional dan pengemasannya. Hal yang paling utama adalah membangun masayarakat yang sadar lingkungan sehingga pengetahuan masyarakat tentang penyebab terjadinya kerusakan dan jenis-jenis kerusakan gua, lukisan dinding gua dan lingkungannya sudah dipahami dan diketahui, sehingga dengan melihat kondisi kerusakan yang terjadi masyarakat sudah mengetahui bagaimana upaya yang dapat dilakukan dalam mengatasi permasalahan yang sedang terjadi.

Untuk mewujudkan partisipasi masyarakat dalam penanganan kerusakan gua-gua prasejarah dan lingkungannya, maka perlu dilakukan pendekatan pengembangan masyarakat. Keberhasilan kegiatan pengembangan suatu wilayah sangat tergantung pada dukungan komunitas disekitarnya, yang karakter secara fisik sosial budaya merupakan sumberdaya utama. Maka pelestarian lingkungan fisik ini perlu memandang masyarakat lokal sebagai sumberdaya yang dinamis yaitu sebagai subjek dan bukan sekedar objek. Pendekatan ini perlu ditempuh karena masyarakat Bellae adalah orangorang yang paling tahu kondisi sosial budaya setempat. Setiap kegiatan yang dilakukan harus memperhitungkan keinginan masyarakat di sekitar wilayah tersebut. Oleh karena itu, setiap langkah keputusan perencanaan harus mencerminkan masyarakat lokal yang secara aktif ikut terlibat didalamnya. Dengan melibatkan masyarakat dari awal maka akan lebih menjamin kesesuaian program pengembangan dengan aspirasi masyarakat setempat, kesesuaian dengan kapasitas yang ada, serta menjamin adanya komitmen masyarakat karena adanya rasa memiliki yang kuat. Dalam melakukan pengembangan masyarakat setempat, ada beberapa kriteria yang perlu diperhatikan yaitu memajukan tingkat hidup masyarakat sekaligus melestarikan identitas budaya dan tradisi lokal, meningkatkan tingkat pendapatan secara ekonomis sekaligus mendistribusikan merata pada masyarakat lokal, berorientasi pada pengembangan usaha berskala kecil dan menengah dengan daya serap tenaga besar dan berorientasi pada teknologi tepat guna, mengembangkan semangat kompetisi sekaligus kooperatif, dan memanfaatkan pariwisata seoptimal mungkin dengan dampak seminimal mungkin.

Merujuk penjelasan di atas mengenai konservasi berbasis masyarakat yang dilakukan di Kompleks Gua Prasejarah Bellae akan memberikan manfaat secara sosial ekonomi secara adil. Manfaat ekonomi yang diperoleh dari kegiatan konservasi ini baik secara langsung maupun tidak langsung akan dinikmati oleh masyarakat Bellae. Manfaatnya yaitu dengan membuka lapangan pekerjaan maupun tambahan penghasilan untuk mendukung kehidupan masyarakat setempat. Distribusi keuntungan dari hasil usaha yang dilakukan tidak hanya diterima oleh masyarakat yang terlibat langsung tapi juga diperoleh oleh seluruh masyarakat Bellae. Keuntungan yang diperoleh bagi masyarakat yang tidak terlibat secara langsung yaitu dengan adanya upaya pembangunan fasilitas seperti perbaikan masjid, perbaikan sarana dan prasarana serta pemberian bantuan terhadap warga yang mengalami musibah seperti sakit atau meninggal. Hasil usaha pelestarian gua-gua prasejarah dan lingkungannya 
yang dikelola oleh masyarakat akan terbagi secara adil, masing-masing pengurus, pekerja, dan seluruh warga menerima bagiannya sesuai dengan porsi dan peranannya dalam pelaksanaan konservasi gua-gua prasejarah dan lingkungannya. Kondisi tersebut sesuai dengan penjelasan Keller dalam Emilia (2013) bahwa pergeseran paradigma konservasi yang dilakukan oleh pemerintah bergeser menjadi konservasi berbasis masyarakat. Hal tersebut akan membantu masyarakat yang selama ini merasa terpinggirkan dan terlupakan menjadikan masyarakat memiliki peran dan memperoleh pendapatan dari usaha konservasi gua-gua prasejarah dan lingkungannya sehingga masyarakat dapat berpartisipasi penuh dalam kegiatan pelestarian, bukan hanya sebagai penonton sebagaimana pelestarian yang selama ini dilakukan oleh pemerintah.

Dalam melakukan usaha konservasi yang berbasis masyarakat di Kompleks Gua Prasejarah Bellae, maka fungsi dan aktivitas harus berjalan dengan baik, memanfaatkan aktivitas dan potensi yang sudah ada serta atas kesepakatan dengan masyarakat setempat. Untuk mewujudkan upaya tersebut maka ada beberapa hal yang harus dilakukan yaitu perencanaan (Planning), pengorganisasian (Organizing), pelaksanaan (Actuating), pengendalian, koordinasi dengan stakeholder, monitoring dan evaluasi, dan strategi keberlanjutan peran masyarakat.

Berdasarkan pemaparan di atas, fungsi dan aktivitas konservasi yang melibatkan masyarakat untuk menjaga kelestarian Kompleks Gua Prasejarah Bellae tidak akan maksimal apabila semua keolompok stakeholder tidak bekerjasama dan tidak terlibat. Untuk memaksimalkan kegiatan tersebut, maka hal utama yang perlu dilakukan adalah penataan lingkungan, penataan pengunjung, dan penataan jalur kunjungan. Upaya ini dilakukan agar kondisi Kompleks Gua Prasejarah Bellae tetap terjaga kelestariannya dan masyarakat Bellae dapat terlibat dan mengawasi secara lansung.

\section{Penutup}

Kompleks Gua Prasejarah Bellae memiliki nilai penting yang sangat tinggi berupa nilai penting sejarah, ilmu pengetahuan, dan nilai penting kebudayaan. Melihat pentingnya kompleks gua ini dalam kajian arkeologi, maka kompleks gua ini perlu mendapat perhatian yang serius. Hal ini seiring dengan berlakunya Undang- undang No.11 Tahun 2010 tentang Cagar Budaya yang memberikan arahan yang jelas dan mengakomodasi berbagai kepentingan tentang perlindungan, pengelolaan, dan pemanfaatan situs cagar budaya untuk sebesarbesarnya kepada kesejahteraan rakyat.

Berdasarkan hasil kajian yang dilakukan Balai Konservasi Borobudur dan hasil penelitian yang telah dilakukan penulis, diketahui bahwa kondisi gua-gua prasejarah dan lingkungannya, saat ini telah mengalami tingkat kerusakan yang cukup tinggi, sehingga perlu dilakukan upaya penanggulangan kerusakan. Kerusakan gua-gua prasejarah pada umumnya disebabkan oleh faktor alam, sehingga mengakibatkan terjadinya pengelupasan pada bagian lapisan dinding gua, pertumbuhan algae, lichen dan moss. Pertumbuhan mikroorganisme pada umumnya terjadi di bagian lapisan dinding batuan yang dilewati oleh aliran air. Selain faktor alam, kerusakan gua-gua dan lingkungannya juga disebabkan oleh aktivitas manusia seperti instansi pemerintah dalam hal ini BPCB Makassar yang membuat akses jalan menuju gua dan dalam zona inti secara permanen. Hal lain yang dilakukan adalah metode pembersihan lingkungan yang dilakukan oleh jupel yang menggunakan sapu lidi untuk membersihkan halaman gua, sedangkan disekitar halaman gua banyak ditemukan artefak. Komunitas peneliti juga tidak sedikit kontribusinya dalam menurunkan kualitas tinggalan arkeologi yang terakumulasi di dalam situs. Peneliti biasanya melakukan ekskavasi pada lantai gua dan halaman gua serta seringkali juga mengambil sampel temuan untuk kepentingan analisis dan untuk kepentingan lainnya. Aktivitas peneliti ini tanpa disadari telah mengakibatkan terjadinya penyusutan pada lantai, halaman gua dan temuan. Catatan mengenai temuan yang diambil sebagai sampel analisis laboratorium masih kurang, tidak menginformasikan dan mempublikasikan hasil-hasil penelitian yang telah dilakukan pada kompleks gua tersebut. Pemanfaatan yang dilakukan oleh masyarakat setempat berupa penebangan pohon disekitar lingkungan gua dan pemanfaatan lahan disekitar gua seperti berkebun dan sawah. Aktivitas yang dilakukan tersebut secara langsung dan tidak langsung memberikan dampak yang negatif terhadap tinggalan yang ada di Kompleks Gua Prasejarah Bellae. Hal lain yang diprediksi dapat mengancam kelestarian Kompleks Gua Prasejarah Bellae adalah penambangan gamping dan marmer. 
BPCB Makassar adalah Instansi pemerintah yang bertanggungjawab terhadap pelestarian dan peninggalan purbakala yang ada di Kompleks Gua Prasejarah Bellae. Dalam usaha perlindungannya, beberapa kebijakan yang telah dilakukan antara lain pembuatan pagar, pengangkatan juru pelihara, studi kelayakan, pemetaan dan pengukuran, studi teknis, pemintakatan (zoning), deliniasi dan kajian sosial. Melalui usaha yang dilakukan oleh BPCB Makassar pada kawasan ini, diharapkan agar kawasan ini akan tetap terjaga kelestariannya. Namun kenyataannya sampai saat ini kondisi gua-gua prasejarah yang ada di kawasan ini terus mengalami kerusakan dan sebagian makin mengkhawatirkan. Upaya perlindungan belum berjalan dengan maksimal. Pembuatan pagar pengaman dan penempatan juru pelihara juga belum memberikan jaminan terhadap kelestarian situs gua-gua prasejarah.

Melihat kondisi kerusakan yang terjadi pada gua-gua prasejarah dan lingkungannya, maka perlu dilakukan upaya konservasi. Konservasi yang dilakukan pada kompleks gua ini tidak dilakukan pada objek semata

\section{DAFTAR PUSTAKA}

Anonim. 1989. Kamus Besar Bahasa Indonesia. Jakarta : Balai Pustaka.

Balai Konservasi Sumber daya Alam Sulawesi Selatan I. 2006. Rencana Pengelolaan Taman Nasional Bantimurung Bulusaraung (2006-2031). Makassar : Dipa Bagian Anggaran 69 Balai KSDA Sulawesi Selatan.

Emilia, Fransisca. 2013. Pengelolaan Sumberdaya Alam

Berbasis Masyarakat dalam Upaya Konservasi Daerah Aliran Sungai (Studi Kasus Desa Keseneng, Kecamatan Sumowono Kabupaten Semarang). Tesis. Semarang: Program Magister Ilmu Lingkungan Universitas Diponegoro.

Sumantri, Iwan. 2004. "Penerapan Kajian Pola Pemukiman Gua Prasejarah di Sulawesi Selatan: Studi Kasus Biraeng". Dalam Iwan Sumantri (ed). Kepingan Mozaik Sejarah Budaya Sulawesi Selatan, pp. 21-171. Makassar: Ininnawa.

Supriadi. 2008. "PemanfaatanKompleks Gua Prasejarah Bellae, Sulawesi Selatan”. Tesis.Yogyakarta: Program Pasca Sarjana Universitas Gadjah Mada. tetapi konservasi yang lebih fokus kepada masyarakat yang ada di sekitar Kompleks Gua Prasejarah Bellae. Dalam melakukan konservasi yang berbasis masyarakat perlu ada sebuah konsep tentang bentuk upaya yang bisa dilakukan dengan melibatkan masyarakat setempat. Konsep yang dibuat adalah dalam bentuk organisasi Desa. Organisasi ini menunjukkan bahwa masyarakat merupakan bagian penting (pemangku kepentingan). dalam pelestarian tinggalan arkeologi dan lingkungannya.

Hasil akhir dari tulisan ini merupakan konsep dasar pelestarian dan rekomendasi agar strategi konservasi dalam menjaga kelestarian Kompleks Gua Prasejarah Bellae bisa dilakukan dengan melibatkan masyarakat. Konsep yang dihasilkan dalam penulisan ini tidak menutup kemungkinan suatu saat akan dievaluasi atau mengalami perubahan, sesuai dengan kebutuhan stakeholder. Namun hal yang perlu diperhatikan adalah apabila terjadi perubahan konsep harus tetap mengutamakan kepentingan masyarakat sekitar Kompleks Gua Prasejarah Bellae dan tetap melibatkan masyarakat dalam mengambil keputusan.

Tanudirjo, Daud Aris. 2005. Peranan Masyarakat dalam Pelestarian Bangunan dan Kawasan Bersejarah. Makalah disampaikan dalam Penguatan Pelestarian Warisan Budaya dan Alam. Badan Pelestari Pusaka Indonesia 22 September 2005. Wibowo, Budi, dkk. 2003. Pemberdayaan Lembaga Mukim dalam Pembangunan Daerah Kota Banda Aceh. Banda Aceh: Badan PerencanaanPembangunan Daerah Kota Banda Aceh.

Wibowo, Budi. Jurnal Konservasi Cagar Budaya Borobudur, Volume 8, Nomor 1, Juni 2014: Hal 58-71. Strategi Pelestarian Benda/Situs Cagar Budaya Berbasis Masyarakat Kasus Pelestarian Benda/Situs Cagar Budaya Gampong Pande Kecamatan Kutaraja Banda Aceh Provinsi Aceh.

Undang-Undang Nomor 11 Tahun 2010 Tentang Cagar Budaya

Http: / /woklegua.blogspot.com/2011/06/kawasankarst-maros-pangkep, diakses tanggal 25.12. pukul 10.38 PM

http://www.nature.com/nature/journal/v514/n7521/ full/nature134222.html 